\title{
PREFACE
}

For almost four hundred years, the King James Bible and Shakespeare formed the twin mother lode of memorable quotations in English. Today, the average American will more likely recall a lyric by Lennon and McCartney or recite a line from Family Guy than chapter and verse from the Psalms or a soliloquy by Hamlet.

Purists may lament this seeming triumph of mass culture over time-tested holy or secular writ. But all is not lost. In our increasingly pixelated world of Snapchat and Twitter, revered authors and texts, past and present, still supply instructive words to live by. Countless no-frills, digitally printed dictionaries and internet domains devoted to quotations attest to this happy fact.

Their bill of fare tends to be drawn from standard works such as Bartlett's Familiar Quotations or websites such as BrainyQuote.com. Often, in cyberspace especially, the language and attributions are defective. Sometimes they are totally wrong. Most people don't care: for them, it's not the words but the message behind the words that counts.

The popularity of quotations, online and in print, reflects a fundamental thirst for wisdom. Their appeal is all the more powerful if the perceived wisdom is curt, clever, and attached to a celebrated name. Concise, insightful observations, artfully contrived-proverbs, maxims, adages, truisms, quips, and so on-have been around forever. Be they anonymous, or credited to eminent statesmen, poets, or pop stars, quotes help us cope with the mysteries and challenges of life. They are comfort food for the mind, and the soul.

Few men or women have brought as much grist to the quotation mill as Voltaire. "All is for the best in this best of all possible worlds" and "We must cultivate our garden," from Candide, are exhibits A and B of his lasting claim on our shared cultural imagination.

"The perfect is the enemy of the good," from Voltaire's Dictionnaire philosophique, ${ }^{1}$ is a favorite with the ruling class in Washington. In a July 2010

I. "The perfect is the enemy of the good" is an English version of a proverb quoted in Italian in "Art Dramatique," an article in Voltaire's Questions sur l'Encyclopédie, par des Amateurs (1770), a text later added to editions of the Dictionnaire philosophique. 
Huffington Post blog, a professor at the University of California, Davis commented on the let's-make-a-deal cynicism he detected in what he called "Obama's Perfect-Is-the-Enemy-of-Good mantra." One instance of Barack Obama's "favorite platitude," as the blogger put it, occurred during the 2008 presidential campaign. Speaking about an offshore drilling bill pending before Congress, candidate Obama said: "I'm willing to consider it if it's necessary to actually pass a comprehensive plan. I am not interested in making the perfect the enemy of the good-particularly since there is so much good in this compromise that would actually reduce our dependence on foreign oil." ${ }^{2}$ Obama's mantra resurfaced in 2013 in connection with legislation to aid victims of Hurricane Sandy. Senator Barbara Mikulski of Maryland, a supporter of the measure, said, "It is not perfect, but it is a very sound bill. Let's not make the perfect the enemy of the good." In March 20I7, Speaker of the House Paul Ryan applied Voltaire's remark to the politics of health care reform. ${ }^{3}$

Voltaire is famous not just for aphorisms like this. He may be equally famous for things he never wrote or said, the most notorious being: "I disapprove of what you say, but I will defend to the death your right to say it." Though faithful to Voltaire's core principles, this impassioned call for freedom of speech sprang from the pen of an Englishwoman, Evelyn Beatrice Hall, shortly after the turn of the last century, in her book, The Friends of Voltaire.

Writing under the alias "S. G. Tallentyre," Hall meant to convey a succinct summary of Voltaire's reaction to news that an atheistic tract by a fellow philosophe, Helvétius (figure 2), had been condemned by the Catholic Church: "What a fuss about an omelette!' he had exclaimed. ... How abominably unjust to persecute a man for such an airy trifle as that! 'I disapprove of what you say, but I will defend to the death your right to say it,' was his attitude now."

Hall's qualifying phrase, "his attitude now," was overlooked by virtually everyone who read what she had written. ${ }^{4}$

Her stirring paraphrase, unequivocally assigned to Voltaire, was carved in stone inside the lobby of the Tribune Tower when the Chicago Tribune's new

2. Bob Ostertag, "Gulf Disaster: The Fatal Flaw in Obama's 'Don't Make the Perfect the Enemy of the Good' Politics," Huffington Post, July 6, 2oro; "Obama's Speech in Lansing, Michigan," New York Times, August 4, 2008.

3. John Hayward, “The Cliffhanger, Jan. 29," Human Events, January 29, 2013; Rebecca Shabad, "Ryan Says He Doesn't Want to Negotiate with Democrats on Health Care," CBS.com, March 30, 2017. This is what Ryan said on that date on CBS This Morning: "If this Republican Congress allows the perfect to become the enemy of the good, I worry we'll push the President to working with Democrats."

4. Hall [S. G. Tallentyre], The Friends of Voltaire (I906), I98-I99. The controversial tract by Helvétius was De l'esprit (1758). 


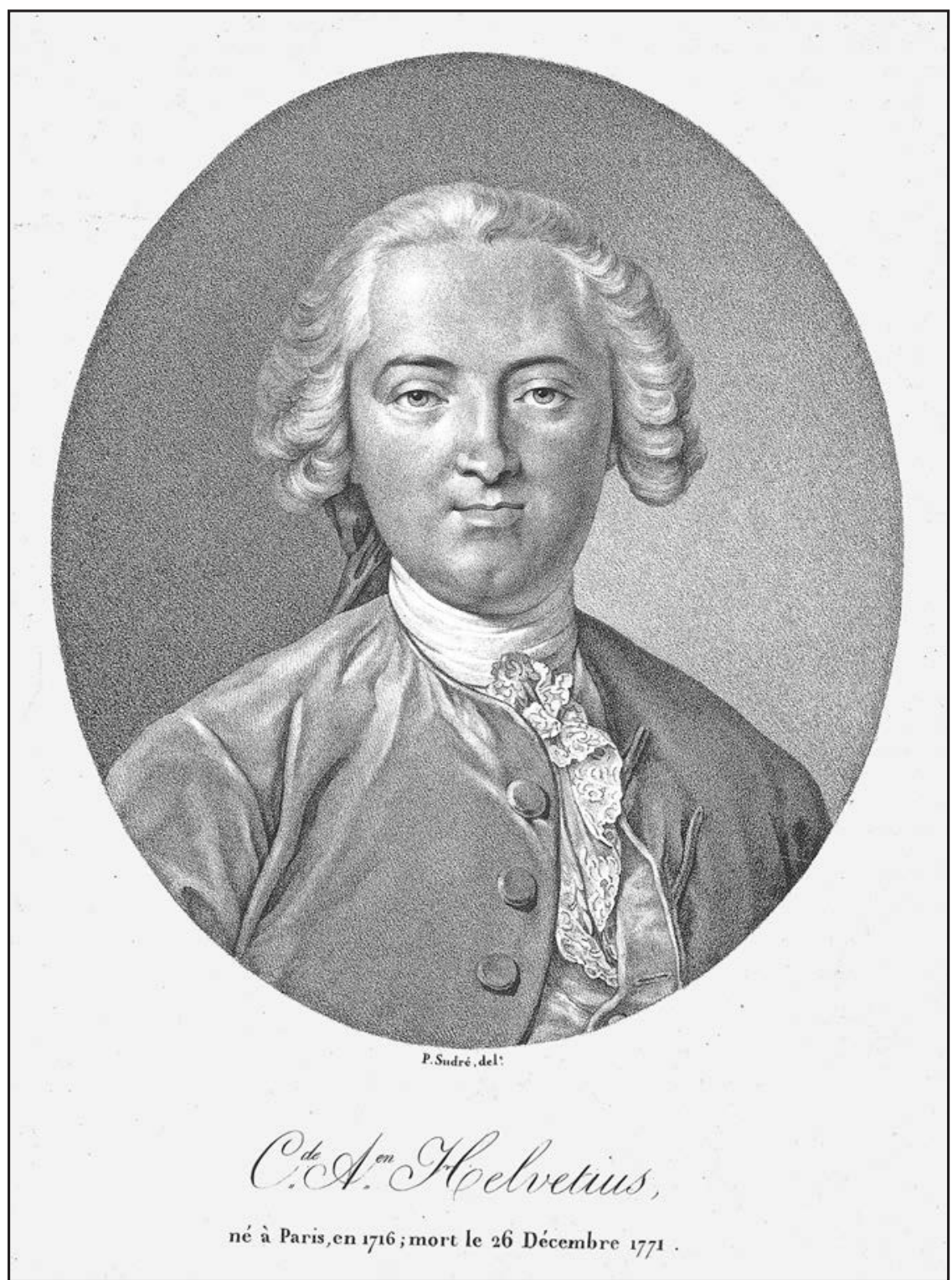

Figure 2. Pierre Sudré, Portrait of Claude-Adrien Helvétius, 1825. Lithograph. Copy of an earlier print after a painting from 1755 by Louis-Michel Van Loo. Private collection.

headquarters building was inaugurated in 1925 (figure 3). In June 1934, Reader's Digest passed the bogus quote on to its national readership. In 1938, it was further fixed in the public mind by the Hollywood film Jezebel, starring Bette Davis, in which a dinner guest declared, "I think it was Voltaire who said, 'I disagree with what you say but I will defend to the death your right to say it." 


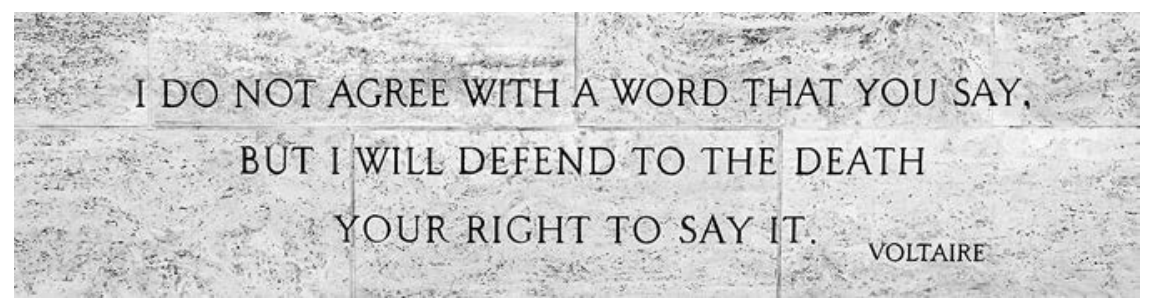

Figure 3. The false "I will defend to the death" quote, carved into the wall of the Hall of Inscriptions in the main lobby of the Chicago Tribune building on Michigan Avenue, Chicago. Photograph by John O’Neill.

Lazy, ignorant postwar writers, journalists, and now denizens of the World Wide Web have made the long-debunked quote one of the most commonly misquoted lines in the language.

Voltaire had opinions—not always polite or "politically correct"-on everything from adultery, friendship, and luxury to testicles and Zoroaster. He was, at times, appallingly malicious.

"The fact that Voltaire devoted his life to the noblest of causes," Lytton Strachey said, "must not blind us to another fact," that he could "be a frantic, desperate fighter, to whom all means were excusable; he was a scoundrel, a rogue, he lied, he blasphemed; he was extremely indecent." ${ }^{5}$ Both the positive and negative facets of Voltaire's character are in evidence among the more than two thousand quotations in The Quotable Voltaire.

In the realm of bons mots, perhaps Voltaire's closest challenger in the eighteenth century was Benjamin Franklin, whose pithy maxims in Poor Richard's Almanack remain an integral part of our vernacular. ${ }^{6}$ Voltaire could be pithy, too. For Nicholas Cronk, director of the Voltaire Foundation, he was "a master of the one-liner." But his droll one-liners, combined with his many other, more expansive statements-shrewd, cynical, or spiteful-surpass in their totality and depth the range of sayings we associate with Franklin. ${ }^{7}$

In 1925, Emanuel Haldeman-Julius, a Socialist reformer in a small town in Kansas, began selling, at a nickel apiece, copies of a softcover booklet, The Wit

5. Strachey, "Voltaire," The Athenaum, August I, I919, 679.

6. See James C. Humes, The Wit E Wisdom of Benjamin Franklin (1995). Besides Franklin, two other Anglophone writers in the eighteenth century were masters of the catchy quote: Alexander Pope and Samuel Johnson.

7. Cronk, "Voltaire and the One-liner," OUPblog, March Io, 2017. 
and Wisdom of Voltaire Famous Skeptic, printed on cheap paper. HaldemanJulius has been described as "one of the most prolific publishers in U.S. history, putting an estimated 300 million copies of inexpensive "Little Blue Books' into the hands of working-class and middle-class Americans." In addition to Voltaire, he helped popularize the writings of Will Durant, Bertrand Russell, and Clarence Darrow. ${ }^{8}$

However, The Wit and Wisdom of Voltaire is mostly an assortment of windy wooden prose of vague or unspecified origin, not a true collection of quotations. The first bona fide compilation of quotes, Satirical Dictionary of Voltaire, was published in 1945 by a professional puppeteer, Paul McPharlin. The lone French dictionary to date, Sarcasmes, compiled by a journalist, Pierre Sipriot, came out in 1989 .

In 1995, three French academics, Jean Goulemot, André Magnan, and Didier Masseau, assembled a massive compendium, Inventaire Voltaire. Scattered throughout its $\mathrm{I}, 368$ articles, contributed by the editors and thirty fellow scholars, are tons of quotable material. In 1994 and in 2013, respectively, a Belgian writer, André Versaille, published two similarly mammoth anthologies of excerpts, drawn à la Haldeman-Julius, from Voltaire's oeuvre: Dictionnaire de la pensée de Voltaire par lui-même and Autodictionnaire Voltaire. These six antecedents of the present book, the first rigorously curated dictionary of quotations by Voltaire, are listed below, beneath our signature line.

The Quotable Voltaire is unique in terms of its substance, accuracy, and bilingual format. This extends to the inclusion of fourteen quotations misattributed or dubiously ascribed to Voltaire. The second half of the book consists of comments about Voltaire, his life and accomplishments, by Voltaire himself, his contemporaries, and posterity.

In compiling The Quotable Voltaire, we relied chiefly on the Euvres completes de Voltaire, the first critical edition of the whole of Voltaire's works, completed in 202I, in 203 volumes, under the aegis of the Voltaire Foundation at the University of Oxford. All entries in our dictionary are nonetheless fully documented, with specific (usually initial) dates of publication and page numbers for every source we cite, since many early non-CEuvres complètes references can be hard to locate. The sole exception to this rule are Voltaire's correspondence and plays. The vast majority of his letters and dramatic works are accessible online or in print in one form or another. ${ }^{9}$

8. For the comment on Haldeman-Julius and his Little Blue Books, see Rolf Potts, "The Henry Ford of Literature," The Believer, September 2008.

9. The most authoritative collection of Voltaire's letters in print is Theodore Besterman's The Complete Works of Voltaire. Correspondence and Related Documents. Definitive 
Each entry in The Quotable Voltaire is presented in parallel versions: in English and the original language, invariably French, but occasionally German, Italian, or Spanish. Due to their historical, cultural, or literary value, translations for a number of quotes date from the eighteenth or nineteenth century, notably the thirty-six-volume series of Voltaire's works edited by the Scottish poet and novelist Tobias Smollett.

In the back of the book, a timeline of events in Voltaire's life and posthumous critical fortunes precedes a list of books, and one documentary film, for further reading (and viewing) in English. A complete bibliography of texts mentioned within these pages appears at the very end of the volume.

\section{Garry Apgar}

Edward M. Langille

Edition (1968-1977), initiated during Besterman's tenure as director of the Institut et Musée Voltaire in Geneva and completed by the Voltaire Foundation at Oxford, now superseded by Electronic Enlightenment (an online research project of the Bodleian Libraries, Oxford; subscription only), which benefits from regular updates and new material. The fifty-one-volume series edited by Besterman contains letters to and by Voltaire. A compact thirteen-volume Pléiade set of the correspondence, culled from Besterman's magnum opus (minus letters to Voltaire), edited by Frédéric Deloffre, has been published by Gallimard. For a relatively complete nineteenth-century edition, available online and thus easily searchable, see Adrien-Jean-Quentin Beuchot, Euvres de Voltaire (I828-I834), vols. 5I-70. 


\section{PREVIOUSLY PUBLISHED BOOKS CONTAINING QUOTATIONS AND EXCERPTS OF WRITINGS BY VOLTAIRE}

The Wit and Wisdom of Voltaire Famous Skeptic. Girard, KA: Haldeman-Julius Company (Little Blue Book No. 6o), 1925. 64 pp.

Paul McPharlin, ed. Satirical Dictionary of Voltaire. New York: Peter Pauper Press, 1945. IIo pp.

Pierre Sipriot, ed. Sarcasmes. Monaco: Editions du Rocher, 1989. 216 pp.

André Versaille, ed. Dictionnaire de la pensée de Voltaire par lui-même. Brussels: Éditions Complexe, I994. I,320 pp.

Jean Goulemot, André Magnan, and Didier Masseau, eds. Inventaire Voltaire. Paris:

Gallimard, 1995. I,422 pp.

André Versaille, ed. Autodictionnaire Voltaire. Paris: Omnibus, 2013. 624 pp. 



\section{The Quotable Voltaire}


